\title{
Perencanaan Strategis Pembangunan Desa Dalam Rangka Pengembangan Potensi Ekonomi Lokal
}

\author{
Benuara Jaya, Entang Adhy Muhtar dan Darto \\ Administrasi Publik, Fakultas Ilmu Sosial dan Ilmu Politik, Universitas Padjadjaran \\ Email korepondensi: benuara.jaya@gmail.com
}

\begin{abstract}
ABSTRAK
Salah satu strategi pembangunan desa untuk meningkatkan kesejahteraan masyarakat dan penanggulangan kemiskinan adalah melalui pengembangan potensi ekonomi lokal. Untuk mewujudkan hal tersebut maka hal pertama yang dilakukan adalah menyusun perencanaan pembangunan desa atau RPJM Desa. Oleh karena itu, pemerintah desa hendaknya menyusun rencana strategis atau rencana kegiatan pembanguna desa yang terarah dan berkelanjutan untuk mengembangkan salah satu potensi ekonomi lokal yang ada diwilayahnya. Penelitian ini bertujuan untuk mengetahui bagaimana perencanaan strategis pembangunan desa yang optimal dalam rangka pengembangan potensi ekonomi lokal. Penelitian dilakukan di Desa Pondok Meja Kecamatan Mestong Kabupaten Muaro Jambi. Metode yang digunakan adalah pendekatan deskriptif kualitatif menggunakan teknik wawancara, observasi dan dokumentasi. Hasil penelitian menunjukkan bahwa terdapat beberapa kekurangan pada perencanaan strategis pembangunan desa dalam rangka pengembangan potensi ekonomi lokal di Desa Pondok Meja seperti belum mengidentifikasi mandat formal dan informal dan belum menentukan isu strategis. Oleh karena itu, perencanaan pembangunan desa perlu memperhatikan dan memperbaiki beberapa kekurangan tersebut.
\end{abstract}

Kata Kunci: Perencanaan Strategis, Pembangunan Desa, Pengembangan potensi ekonomi lokal

\section{ABSTRACT}

One of the village development strategies in improving community welfare and reducing poverty is through the development of local economic potential as stated in Law Number 6 of 2014 concerning Villages. To realize this, the first thing the village does is to prepare a village development plan or RPJM Desa. Therefore, village government prepares a strategic plan or activity plan for village development that is directed and sustained to develop one of its areas. This study aims to determine how to plan optimal village development strategies in the context of developing local economic potential. The research was conducted in Pondok Meja Village, Mestong District, Muaro Jambi Regency, by using a qualitative descriptive approach using interview, observation and documentation techniques. The results indicate that there are several shortcomings at the planning stage of village development strategies in Pondok Meja Village such as not identifying formal and informal mandates and not determining strategic issues. In order to be optimal, village development planning process needs to pay attention and to correct some of these shortcomings.

Keywords: Strategic Planning, Village Development, Development of local economic potential 


\section{PENDAHULUAN}

Melalui Undang-Undang Nomor 6 Tahun 2014 tentang Desa, paradigma pembangunan desa berubah dari objek pembangunan menjadi subjek atau aktor utama yang melaksanakan pembangunan desa. Untuk itu, desa harus mampu melaksanakan proses pembangunan mulai dari perencanaan, pelaksanaan dan pengawasan. Yang menjadi tantangannya adalah bagaimana pemerintah pusat dan daerah dapat memampukan desa dalam melaksanakan pembangunan (Eko, 2014). Dengan semakin baik kemampuan desa dalam melaksanakan pembangunan, maka diharapkan manfaat yang dirasakan melalui pembangunan desa semakin besar dirasakan oleh masyarakat.

Tujuan pembangunan desa berdasarkan Undang-Undang Nomor 6 Tahun 2014 tentang Desa dan Peraturan Pemerintah Nomor 43 Tahun 2014 tentang Peraturan Pelaksana UndangUndang Nomor 6 Tahun 2014 tentang Desa adalah meningkatkan kesejahteraan masyarakat desa dan kualitas hidup manusia serta penanggulangan kemiskinan melalui pemenuhan kebutuhan dasar, pembangunan sarana dan prasarana desa, pengembangan potensi ekonomi lokal, dan pemanfaatan sumber daya alam dan lingkungan secara berkelanjutan. Agar tujuan tersebut dapat terwujud, maka yang perlu diperhatikan pertama kali adalah perencanaan pembangunan desa. Sebagaimana terkandung dalam konsep manajemen dalam organisasi untuk mencapat tujuan, maka langkah pertama yang dilakukan adalah menyusun perencanaan. Melalui perencanaan akan ditentukan kegiatan-kegiatan yang akan dilaksanakan, bagaimana, kapan dan oleh siapa, untuk mencapai tujuan yang maksimal dengan menggunakan sumber daya yang ada (Muhammad, 2017). Selain itu, penentuan kegiatan dalam perencanaan pembangunan di desa juga hendaknya memikirkan bagaimana keberlanjutan dan mengurangi kesenjangan pendapatan diantara masyarakat untuk mewujudkan pembangunan ekonomi (Dandekar, 2015).

Untuk mendukung pencapaian tujuan pembangunan desa, maka pemerintah memberikan bantuan berupa Dana Desa yang menjadi salah satu sumber pendapatan desa. Kebijakan ini tertuang dalam Peraturan Pemerintah Nomor 60 Tahun 2014 tentang Dana Desa yang bersumber dari Anggaran Pendapatan dan Belanja Negara. Untuk mengoptimalkan penggunaan dana desa tersebut, maka pemerintah menetapkan kebijakan terkait prioritas penggunaan dana desa dalam menunjang program pembangunan desa dan pemberdayaan masyarakat. Kebijakan tersebut ditetapkan melalui Kementerian Desa, Pembangunan Daerah tertinggal, dan Transmingrasi setiap tahunnnya untuk dijadikan pedoman dalam menyusun kegiatan perencanaan pembangunan desa. Dengan adanya dana desa, maka secara umum dapat memberikan bantuan yang berarti bagi pemerintah desa dan masyarakat dalam pembangunan desa untuk meningkatkan perekonomian, sosial dan politik di desa (Sofianto, 2017).

Secara umum prioritas dana desa mulai dari tahun 2016 sampai dengan 2020, memperhatikan alur pembangunan yang dimulai dari infrastruktur dasar, infrastruktur ekonomi, pengembangan ekonomi produktif, infrastruktur sosial dasar, dan peningkatan kapasitas tenaga kerja. Kemudian kegiatan yang berkaitan dengan peningkatan ekonomi masyarakat juga lebih banyak menjadi perhatian. Terutama bagi desa dengan kategori desa berkembang, desa maju dan desa mandiri. Bagi kategori desa tersebut, upaya peningkatan ekonomi masyarakat difokuskan kepada pengembangan ekonomi produktif dan pengembangan produk unggulan desa yang dikelola oleh BUMDesa. Secara umum isu dalam pembangunan desa meliputi kemiskinan, rendahnya pendapatan, pengangguran, dan kesenjangan wilayah (Nugroho \& Dahuri, 2016). Maka dari itu, bagi desa yang termasuk dalam kategori desa berkembang dan selanjutnya, perlu memperhatikan strategi peningkatan ekonomi masyarakat. Hal ini merupakan mandat dalam pembangunan desa yang mesti dijadikan pedoman. Karena mandat merupakan kewajiban yang harus dilaksanakan oleh organisasi sehingga berimplikasi pada tindakan yang harus dilakukan (Bryson \& Alston, 2010). 
Pengembangan potensi ekonomi lokal merupakan salah satu strategi pembangunan yang mengutamakan peningkatan peluang kerja, pendapatan rumah tangga, pengangguran dan pengurangan kemiskinan bagi penduduk lokal (Saragih, 2015). Pengembangan potensi ekonomi lokal juga dapat muwujudkan kemandirian desa yang berdampak kepada peningkatan ekonomi masyarakat (Sidik, 2015). Ini sejalan dengan tujuan pengembangan usaha ekonomi produktif dan produk unggulan desa yang terkandung dalam prioritas penggunaan dana desa. Tujuannya adalah menciptakan dan mengembangkan aktivitas ekonomi oleh rumah tangga atau kelompok masyarakat dengan berbasis sumber daya lokal untuk meningkatkan penghasilan masyarakat terutama bagi keluarga miskin, membuka lapangan kerja, dan meningkatkan pendapatan asli desa. Dengan demikian perencanaan pembangunan desa perlu memperhatikan strategi pengembangan potensi ekonomi lokal melalui pengembangkan usaha ekonomi produktif dan produk unggulan desa berbasis potensi dan sumber daya lokal. Hasil yang diharapkan adalah meningkatnya pendapatan masyarakat dan bertambahnya kesempatan kerja (Martati \& Syarifuddin, 2013) dan juga berdampak pada peningkatan kesejahteraan masyarakat dan berkurangnya angka kemiskinan (Sayuti, 2011; Susanti, 2013; Zulkarnaen, 2016).

RPJM Desa merupakan perencanaan pembangunan desa yang disusun oleh Pemerintah desa bersama dengan BPD dan unsur masyarakat. Secara umum memuat tentang kondisi umum desa, visi dan misi kepala desa, arah kebijakan pembangunan desa, serta rencana program dan kegiatan desa yang menjadi pedoman dalam pelaksanaan pembangunan untuk 6 tahun kedepan. Kemudian, RPJM Desa menjadi dasar dalam penyusunan RKP Desa yang memuat rencana detail untuk melaksanakan program dan kegiatan desa untuk satu tahun pelaksanaan. Dengan melihat karakteristik tersebut, maka dapat dikatakan RPJM Desa adalah produk dari proses perencanaan strategis yang ada di desa sebagai upaya untuk mencapai tujuan pembangunan desa. Perencanaan strategis dapat diartikan sebagai upaya untuk menentukan keputusan atau tindakan dimasa depan tentang apa yang perlu dilakukan dan mengapa dilakukan oleh suatu organisasi atau entitas lainnya untuk menjadi pedoman dalam mencapai tujuannya (Bryson, Crosby, \& Bryson, 2009).

Berdasarkan uraian diatas, maka terdapat suatu permasalahan yang terjadi di Desa Pondok Meja. Desa Pondok Meja adalah salah satu desa di wilayah Kecamatan Mestong, Kabupaten Muaro Jambi. Desa ini memiliki beberapa potensi ekonomi lokal seperti karet, sawit, kunyit, pinang, ternak kambing dan ayam. Dari beberapa potensi tersebut, komoditas yang dikenal oleh banyak orang baik dari dalam maupun luar desa adalah tanaman kunyit. Maka dari itu, tanaman kunyit memiliki kesempatan besar untuk dikembangkan sebagai produk unggulan desa dan usaha ekonomi produktif sebagai bentuk pengembangan potensi ekonomi lokal desa. Hanya saja dalam RPJM Desa Pondok Meja Tahun 2019-2025 yang disusun pada akhir tahun 2019 belum menguraikan rencana strategis untuk pengembangan potensi ekonomi lokal yang mengarah pada produk unggulan desa terutama untuk tanaman kunyit.

Tabel 1. Rencana Pembangunan Desa Terkait Pengembangan Potensi Ekonomi Lokal pada RPJM Desa Pondok Meja Tahun 2019-2025

\begin{tabular}{|c|c|c|c|c|c|c|c|c|}
\hline \multirow{2}{*}{ No } & \multirow[t]{2}{*}{ Program/Kegiatan } & \multirow[t]{2}{*}{ Volume } & \multicolumn{6}{|c|}{ Rencana Tahun Pelaksanaan } \\
\hline & & & hn 1 & hn 2 & hn 3 & hn 4 & hn 5 & in 6 \\
\hline 1. & Igembangan dan pengadaan bibit sawit & $450 \mathrm{Ha}$ & & & & $\sqrt{ }$ & & \\
\hline 2. & emajaan kebun karet & $500 \mathrm{Ha}$ & & & & $\sqrt{ }$ & & \\
\hline 3. & Igembangan dan pengadaan bibit sapi & $6 \mathrm{Klp}$ & & & & & $\sqrt{ }$ & \\
\hline 4. & Igembangan dan pengadaan bibit kambing & $6 \mathrm{Klp}$ & & & & & $\sqrt{ }$ & \\
\hline 5. & ıgembangan dan pengadaan bibit ikan & 0.000 ekor & & & & & & $\sqrt{ }$ \\
\hline 6. & nbangunan pelelangan karet. & 1 unit & & & & & & $\sqrt{ }$ \\
\hline 7. & nbangunan kios pasar desa & 4 unit & & & & & & $\sqrt{ }$ \\
\hline 8. & Igembangan dan pengadaan bibit buah & $30 \mathrm{Ha}$ & & & & & $\sqrt{ }$ & \\
\hline
\end{tabular}




\begin{tabular}{|c|c|c|c|c|c|c|c|c|}
\hline 9. & Igembangan dan pengadaan bibit palawija & $6 \mathrm{Ha}$ & & & & & $\sqrt{ }$ & \\
\hline 10. & Igadaan kolam ikan baru & $3 \mathrm{Ha}$ & & & & & $\sqrt{ }$ & \\
\hline 11. & nberian bantuan modal usaha bagi masyarakat & 6 Dsn & $\sqrt{ }$ & $\sqrt{ }$ & $\sqrt{ }$ & $\sqrt{ }$ & $\sqrt{ }$ & $\sqrt{ }$ \\
\hline 12. & ıgadaan bibit sayuran & $25 \mathrm{Ha}$ & & & & & & $\sqrt{ }$ \\
\hline 13. & ıgembangan BUMDes & 1 paket & & & & $\sqrt{ }$ & & \\
\hline 14. & atihan keterampilan pemuda & 60 org & $\sqrt{ }$ & $\sqrt{ }$ & $\sqrt{ }$ & $\sqrt{ }$ & $\sqrt{ }$ & $\sqrt{ }$ \\
\hline 15. & atihan bagi perempuan & 60 org & $\sqrt{ }$ & $\sqrt{ }$ & $\sqrt{ }$ & $\sqrt{ }$ & $\sqrt{ }$ & $\sqrt{ }$ \\
\hline 16. & atihan petani karet & 60 org & & & & & $\sqrt{ }$ & \\
\hline 17. & atihan BUMDes & 5 org & & & & & $\sqrt{ }$ & \\
\hline 18. & atihan Home Industri & 60 org & & & & & $\sqrt{ }$ & \\
\hline 19. & atihan tata boga & 60 org & & & & & $\sqrt{ }$ & \\
\hline 20. & atihan menjahit & 60 org & & & & & & $\sqrt{ }$ \\
\hline 21. & atihan TTG & 30 org & $\sqrt{ }$ & $\sqrt{ }$ & $\sqrt{ }$ & $\sqrt{ }$ & $\sqrt{ }$ & $\sqrt{ }$ \\
\hline
\end{tabular}

Dari tabel 1 diatas terlihat bahwa RPJM Desa Pondok Meja belum fokus dalam menentukan arah pengembangan potensi ekonomi lokal yang ditandai dengan banyaknya ragam produk komoditas yang direncanakan untuk dikembangkan seperti sawit, karet, sapi, kambing, buahbuahan dan palawija. Jika ditinjau dari rata-rata jumlah anggaran yang dimiliki oleh Desa Pondok Meja dari tahun 2017-2019 yaitu sekitar 1,57 milyar (Dinas Pemberdayaan Masyarakat dan Desa, 2020) maka rencana kegiatan diatas menjadi tidak realistis untuk dilaksanakan. Karena dari jumlah total anggaran, sebanyak 30\% dialokasikan untuk operasional dan $70 \%$ dialokasikan untuk pembangunan. Selain itu juga rencana pembangunan diatas memiliki banyak ragam dan kurang memiliki strategi atau pola rangkaian berkelanjutan untuk mencapai tujuan. Maka, potensi lokal yang hendak dikembangkan sebagai produk unggulan desa menjadi belum jelas. Hal ini mengindikasikan bahwa penyusunan RPJM Desa Pondok Meja belum menjalankan perencanaan strategis dengan optimal. Dengan demikian penelitian ini membahas tentang bagaimana perencanaan strategis pembangunan desa yang optimal dalam rangka pengembangan potensi ekonomi lokal di Desa Pondok Meja.

\section{TINJAUAN PUSTAKA}

Perencanaan strategis didefinisikan sebagai upaya secara disiplin untuk menghasilkan keputusan dan tindakan mendasar, yang membentuk dan memandu apa itu organisasi (atau entitas lain), apa yang dilakukannya, dan mengapa ia melakukannya (Bryson, 2004). Pembahasan penelitian ini menggunakan model "The Strategy Change Cycle" yang menguraikan tahapan perencanaan strategis menjadi 10 tahapan yang terdiri dari Initiate and agree on a strategic planning process, Identify organizational mandates, Clarify organizational mission and values, Assess the external and internal environments, Identify the strategic issues facing the organization, Formulate strategies to manage the issues, Review and adopt the strategies or strategic plan, Establish an effective organizational vision, Develop an effective implementation process, Reassess the strategies and the strategic planning process (Bryson, 2004). Model ini dibentuk khusus untuk organisasi sektor publik dan organisasi non profit, yang dapat diaplikasikan pada berbagai tingkatan organisasi pemerintah, fungsi, kolaborasi, dan wilayah atau regional. Selain itu, model ini juga memiliki kesamaan dengan tahapan dalam penyusunan RPJM Desa.

\section{METODE PENELITIAN}

Penelitian ini menggunakan pendekatan kualitatif yaitu mencari pemahaman dengan membangun sebuah gambaran yang menyeluruh dan kompleks dari sebuah masalah sosial atau manusia (Creswell, 2016). Dalam pengumpulan data, penelitian ini menggunakan teknik 
wawancara untuk memperoleh informasi dan cara pandang dari informan, teknik observasi berupa pengamatan langsung ke lokasi penelitian dan teknik dokumentasi berupa pengumpulan dokumen dan foto kegiatan yang relevan. Informan yang dilibatkan dalam penelitian ini mulai dari Kepala Bidang Administrasi Pemerintahan Desa, Pendamping Lokal Desa, Kasi Pemberdayaan Masyarakat Desa Kecamatan Mestong, Kepala Desa, Sekretaris desa, Anggota BPD, Pelaku ekonomi di desa, Ketua LPM dan Perwakilan RT. Selanjutnya, analisis data dilakukan dengan menggunakan teknik Qualitative Data Analysis yang terdiri dari pengumpulan data, reduksi data, penyajian data, dan kesimpulan (Miles \& Huberman, 1994).

\section{HASIL DAN PEMBAHASAN}

\section{Inisiasi dan kesepakatan dalam proses perencanaan strategis.}

Tahapan pertama yaitu Initiate and agree on a strategic planning process dilakukan untuk mendapatkan kesepakatan awal antara pemerintah dan stakeholder tentang kegunaan atau tujuan dari penyusunan perencanaan strategis dan tahapan apa saja yang perlu dilakukan (Bryson, 2004). Tahapan ini juga dapat menumbuhkan dukungan dan komitmen dari para stakeholder (Zuhaidha, Santoso, \& Maesaroh, 2014). Disini perlu perlibatan stakeholder terkait untuk mendapatkan informasi tentang kebutuhan dan harapan yang perlu dipenuhi agar memperjelas arah kebijakan perencanaan. Pelibatan stakeholder sangat penting dalam perencanaan strategis, karena kunci kesuksesan dari organisasi publik dan non profit adalah kepuasan dari stakeholder utama (Light, 1998). Kepuasan tersebut diperoleh melalui pemenuhan kebutuhan dan harapan yang dibahas dan disepakati bersama tentang apa yang paling penting untuk dipenuhi.

Berdasarkan Peraturan Menteri Desa, PDT, dan Transmigrasi Nomor 17 Tahun 2019, tahap pertama dalam penyusunan RPJM Desa adalah menyelenggarakan musyawarah desa yang dihadiri oleh pemerintah desa, seluruh anggota BPD dan perwakilan unsur-unsur masyarakat desa. Musyawarah desa dilaksanakan untuk membahas visi misi kepala desa, pokok-pokok pikiran BPD, dan prakarsa unsur masyarakat. Namun, pelaksanaannya di Desa Pondok Meja, tidak semua unsur masyarakat hadir seperti perwakilan masyarakat miskin dan kelompok tani kunyit. Padahal keterlibatan stakeholder pada kesepakatan awal dalam proses perencanaan strategis sangat dibutuhkan. Keterlibatan stakeholder tersebut tidak hanya dalam memberikan dukungan atau komitmen, tapi yang paling penting adalah mereka menyediakan informasi yang vital bagi upaya perencanaan strategis (Bryant, 2002) dan masing-masing stakeholder memiliki informasi yang khusus, yang tidak bisa diperoleh dari stakeholder lainnya (Thomas \& Thomas, 1995).

Kemudian dalam musyawarah desa, pembahasan yang paling dominan adalah penentuan Tim Penyusun RPJM Desa. Sedangkan pembahasan tentang kebutuhan dan harapan masyarakat yang terkandung dalam pokok-pokok pikiran BPD dan prakarsa unsur masyarakat belum dilakukan, terutama yang berkaitan dengan perekonomian masyarakat. Penyampaian rencana pembangunan baru disampaikan secara umum. Dengan demikian, kesepakatan yang dihasilkan dari musyawarah desa belum mencantumkan atau mengakomodir kebutuhan atau harapan masyarakat khususnya pengembangan potensi ekonomi desa. Padahal kebutuhan dan harapan tersebut dapat digali melalui informasi dari para stakeholder. Dari informasi tersebut dapat menghasilkan gambaran yang menjadi kebutuhan atau harapan stakeholder. Kemudian kebutuhan dan harapan tersebut dapat digunakan sebagai indikator dalam menentukan apa yang harus dilakukan (Rainey, 2009). Oleh karena itu, dalam musyawarah desa hendaknya melibatkan stakeholder untuk memberikan dukungan dan informasi khusus dalam pembahasan dan kesepakatan tentang kebutuhan dan harapan masyarakat. Selanjutnya hal tersebut menjadi pedoman dalam tahapan penyusunan perencanaan pembangunan berikutnya. 


\section{Mengidentifikasi mandat organisasi.}

Tahapan kedua yang dilakukan adalah Identify organizational mandates. Pada tahap ini, berupaya untuk mengidentifikasi apa yang menjadi mandat organisasi. Mandat organisasi dapat diartikan sebagai kewajiban atau tugas yang harus dilakukan atau tidak boleh dilakukan oleh suatu organsasi (Bryson, 2004). Hal ini perlu diketahui dengan jelas baik secara formal maupun informal, agar organisasi memiliki batasan tentang apa yang mesti dilakukan atau kebutuhan apa yang harus dipenuhi (Bryson, 2004). Kemudian Bryson (2004) menjelaskan bahwa mandat formal cenderung dapat diketahui atau ditemukan dalam aturan-aturan yang menjadi pedoman bagi organisasi tersebut, seperti undang-undang, peraturan pemerintah, peraturan menteri, peraturan daerah dan peraturan lainnya yang diakui oleh negara. Sedangkan untuk mandat informal dapat ditemukan pada norma, kebutuhan dan harapan stakeholder. Dengan demikian untuk mengidentifikasi mandat pembangunan desa terkait pengembangan potensi ekonomi desa, maka perlu menelusuri, menelaah dan menganalisa peraturan serta kebutuhan dan harapan masyarakat terkait hal tersebut.

Pemerintah Desa Pondok Meja dan Tim Penyusun RPJM Desa secara umum mengetahui dan memahami apa yang menjadi tututan atau tugas secara formal terkait pengembangan potensi ekonomi lokal desa yang terkandung dalam peraturan. Hanya saja tugas-tugas tersebut belum diuraikan secara terperinci kedalam sebuah daftar atau matriks. Dengan demikian pengetahuan dan pemahaman tersebut hanya secara gambaran umum atau mendasar seperti pentingnya meningkatkan pendapatan masyarakat dan membantu masyarakat miskin. Jika ditelusuri dan disusun secara terperinci, maka dapat diketahui secara spesifik apa yang perlu dilakukan dalam pengembangan potensi ekonomi lokal. Pada tabel berikut dapat diketahui batasan yang mesti dilakukan dan ditindaklanjuti dalam rangka pengembangan potensi ekonomi desa, agar penyusunan rencana strategis lebih terarah.

Tabel 2. Mandat Formal Pengembangan Potensi Ekonomi Lokal Desa

\begin{tabular}{|c|c|c|}
\hline & UU No. 6/2014 & 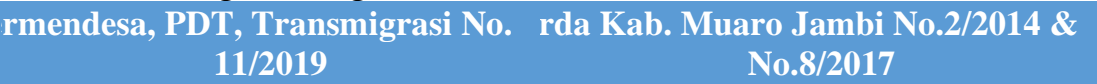 \\
\hline a. & $\begin{array}{l}\text { Memprioritaskan } \\
\text { pengembangan ekonomi } \\
\text { pertanian berskala } \\
\text { produktif }\end{array}$ & 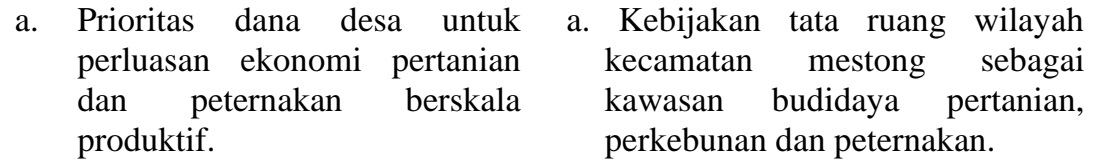 \\
\hline \multirow[t]{2}{*}{ b. } & \multirow[t]{2}{*}{$\begin{array}{l}\text { Memprioritaskan } \\
\text { pengembangan dan } \\
\text { pemanfaatan TTG untuk } \\
\text { kemajuan ekonomi }\end{array}$} & $\begin{array}{l}\text { Kebijakan tata ruang untuk } \\
\text { wilayah Kabupaten Muaro Jambi } \\
\text { untuk mendorong pengembangan } \\
\text { pertanian modern, pemasaran }\end{array}$ \\
\hline & & $\begin{array}{l}\text { c. Prioritas dana desa untuk } \\
\text { penguatan usaha ekonomi } \\
\text { masyarakat melalui BUMDes }\end{array}$ \\
\hline
\end{tabular}

Selanjutnya untuk memperjelas tindakan atau kebutuhan yang harus dipenuhi, maka perlu diketahui apa yang menjadi kebutuhan dan harapan masyarakat. Namun sebagaimana dijelaskan pada tahapan pertama, maka Desa Pondok Meja belum menyusun dan menyepakati apa yang menjadi kebutuhan dan harapan masyarakat terkait pengembangan potensi ekonomi lokal desa. Berdasarkan analisis hasil wawancara dengan perangkat desa, BPD dan tokoh masyarakat, harapan masyarakat Desa Pondok Meja adalah mengarah kepada peningkatan pendapatan dan mengurangi pengangguran. Jika dikaitkan dengan ekonomi produktif dan produk unggulan desa sebagaimana terdapat pada mandat formal, maka semua informan mengarahkan kepada pengembangan tanaman kunyit yang sudah dikenal baik masyarakat desa maupun luar desa. Hal tersebut jika disepakati sebagai kebutuhan dan harapan masyarakat, 
maka dapat menjadi mandat informal yang memperjelas tindakan atau kebutuhan yang harus dipenuhi melalui pembangunan desa. Dengan demikian, Desa Pondok Meja perlu mengidentifikasi dan menginterpretasi mandat formal dan informal secara terperinci agar memperjelas tindakan yang perlu dilakukan dalam pembangunan desa.

\section{Memperjelas misi organisasi.}

Tahapan yang ketiga yaitu Clarify organizational mission and values. Tahapan ini dilakukan untuk memperjelas apa yang menjadi misi organisasi. Misi adalah upaya atau tindakan yang akan dilakukan organisasi untuk menanggapi mandat formal dan informal. Artinya misi memiliki kandungan tujuan yang ingin diwujudkan oleh organisasi dan menjadi rasional untuk langkah ke depan (Bryson, 2004). Dengan memperjelas misi, maka organisasi akan fokus pada apa yang benar-benar penting dalam pembahasan perencanaan strategis. Untuk itu, pada tahapan ini perlu menentukan apa yang menjadi kebutuhan dasar yang harus dipenuhi.

Kebutuhan dasar bagi organisasi tertuang dalam mandat formal dan informal yang telah diidentifikasi pada tahapan sebelumnya. Kemudian organisasi dapat menentukan tindakan yang harus dilakukan untuk memenuhi kebutuhan dasar tersebut, yang selanjutnya dirumuskan menjadi sebuah misi. Kenyataannya, misi dalam RPJM Desa Pondok Meja dirumuskan oleh calon kepala desa pada saat pemilihan kepala desa. Setelah terpilih, Tim Penyusun RPJM Desa menggabungkan misi calon kepala desa terpilih dengan misi dari calon kepala desa lainnya untuk menjadi misi dalam RPJM Desa. Hal tersebut dilakukan atas izin dari kepala desa yang terpilih dengan tujuan menutupi kekurangan pernyataan misi kades terpilih, sehingga yang awalnya hanya 6 misi bertambah menjadi 9 misi. Akan tetapi, pembahasan misi ini belum mengkaji mandat dan kebutuhan dasar Desa Pondok Meja terutama terkait pengembangan potensi ekonomi lokal. Dengan demikian misi yang ada belum menyatakan dengan jelas apa yang akan dilakukan dan bagaimana cara untuk memenuhi kebutuhan mendasar tersebut.

Tabel 3. Perumusan Misi Rencana Pembangunan Desa Dalam Rangka Pengembangan Potensi Ekonomi Lokal

\begin{tabular}{|c|c|}
\hline Kebutuhan Dasar & Perkiraan Tindakan \\
\hline Peningkatan pendapatan masyarakat & \multirow{4}{*}{$\begin{array}{l}\text { Meningkatkan pendapatan masyarakat dan } \\
\text { membuka lapangan kerja dengan mengembangkan } \\
\text { produk unggulan desa. }\end{array}$} \\
\hline Tersedia lapangan kerja & \\
\hline $\begin{array}{l}\text { c. Sumber penghasilan lain/tambahan bagi } \\
\text { masyarakat. }\end{array}$ & \\
\hline Pengembangan kunyit sebagai produk unggulan & \\
\hline
\end{tabular}

Berdasarkan mandat formal dan informal yang diidentifikasi pada tahapan kedua, maka pernyataan misi yang dapat dirumuskan terkait pengembangan potensi ekonomi lokal di Desa Pondok Meja dapat dilihat pada tabel 3. Dari proses ini, maka akan semakin memperjelas tindakan yang akan dilakukan dalam perencanaan pembangunan desa sesuai dengan tuntutan dan kebutuhan. Setelah disepakati, tindakan berikutnya dapat ditetapkan menjadi pernyataan salah satu misi dan tujuan dari pembangunan desa yang jelas. Dengan semakin jelasnya misi organisasi, maka organisasi dapat memfokuskan pembahasan strategi pada apa yang benarbenar penting (Bryson, 2004). Tujuan organisasi yang jelas juga akan mempengaruhi hasil kinerja dengan signifikan, karena salah satu faktor terpenting untuk pencapaian tujuan adalah kejelasan tujuan itu sendiri. Semakin spesifik tujuannya akan semakin besar kemungkinan tercapainya (Nutt, 2002; Sawhill \& Williamson, 2001).

\section{Penilaian lingkungan eksternal dan internal organisasi.}

Tahapan keempat dari proses perencaan strategis yaitu Assess the external and internal environments. Pada tahapan ini, organisasi berusaha memahami dimana posisi mereka terhadap kondisi eksternal dan internal agar dapat mengembangkan strategi yang efektif untuk 
menghubungkan kedua kondisi tersebut, sehingga public value dapat tercipta (Bryson, 2004). Pada tahapan ini, dilakukan penilaian atau pengkajian terhadap kondisi eksternal yaitu Opportunities and Threat/Challanges berupa peluang dan tantangan yang dihadapi oleh organisasi, serta penilaian atau pengkajian kondisi internal yaitu Strengths and Weekness berupa kekuatan dan kelemahan yang dimiliki untuk menghadapi peluang dan tantangan tersebut. Tujuannya adalah untuk mendapatkan informasi yang mendukung terhadap pembuatan ide-ide untuk memandu penyusunan rencana strategis. Dengan demikian pada tahapan ini perlu dilakukan pendataan informasi tentang peluang dan tantangan serta informasi tentang kekuatan dan kelemahan.

Dalam aplikasinya, Tim Penyusun RPJM Desa Pondok Meja telah berupaya melakukan pengkajian keadaan lingkungan dengan cara menggali dan mengumpulkan informasi tentang aset desa, potensi dan masalah yang ada didesa. Kegiatan tersebut dilaksanakan melalui pendataan profil desa dan penggalian gagasan dusun dengan cara menyelenggarakan musyawarah ditingkat dusun. Dari kegiatan tersebut, didapat informasi tentang potensi dan masalah yang diklasifikasikan berdasarkan bidang-bidang seperti pendidikan, kesehatan, ekonomi, sosial budaya dan infrastruktur.

Terkait pengembangan potensi ekonomi desa maka diperoleh informasi potensi ekonomi seperti budidaya jamur, tanaman kunyit, kolam ikan dan potensi lainnya yang ada di setiap wilayah dusun. Kemudian informasi masalah juga diperoleh seperti kurangnya pengetahuan dan keterampilan masyarakat dalam pertanian dan permasalahan lainnya berdasarkan masukan dari masyarakat. Hanya saja dalam penggalian informasi belum menggunakan misi atau arah tujuan pembangunan yang jelas dan spesifik. Oleh karena itu, penggalian informasi menjadi melebar kesemua permasalahan dan kurang fokus, sehingga banyak sekali usulan dan masukan dari masyarakat tetapi kurang memberikan informasi yang mendalam. Kemudian, kekuatan dan kelemahan serta peluang dan tantangan dari setiap potensi yang ada belum dapat ditentukan dari informasi yang didapat.

Tabel 4. Penilaian (SWOT) Pengembangan Tanaman Kunyit di Desa Pondok Meja

\begin{tabular}{|c|c|c|}
\hline & $\begin{array}{c}\text { Faktor yang dapat membantu } \\
\text { pencapaian tujuan }\end{array}$ & $\begin{array}{c}\text { Faktor yang dapat menghalangi } \\
\text { pencapaian tujuan }\end{array}$ \\
\hline $\begin{array}{l}\text { Kondisi } \\
\text { Internal }\end{array}$ & $\begin{array}{l}\text { Kekuatan (Strenghts) } \\
\text { a. Tersedianya anggaran (prioritas dana } \\
\text { desa). } \\
\text { b. Desa memiliki kewenangan melaksanakan } \\
\text { kegiatan pengadaan bibit, pelatihan, } \\
\text { pemasaran dan lain-lain. } \\
\text { c. Tersedia BUMDes untuk dijadikan mitra. }\end{array}$ & $\begin{array}{l}\text { Kelemahan (Weakness) } \\
\text { a. Terbatasnya anggaran. } \\
\text { b. PADes masih sedikit. } \\
\text { c. Kegiatan terbatas pada usulan, perlu rangkaian } \\
\text { kegiatan yang komprehensif. } \\
\text { d. BUMDes belum ada unit usaha pertanian dan } \\
\text { perdagangan. }\end{array}$ \\
\hline $\begin{array}{l}\text { Kondisi } \\
\text { Eksternal }\end{array}$ & $\begin{array}{l}\text { Peluang (Opportunities) } \\
\text { a. Nilai jual dan permintaan yang tinggi. } \\
\text { b. Pengembangan tanaman kunyit dilahan- } \\
\text { lahan kosong atau pekarangan. } \\
\text { c. Pengolahan kunyit menjadi serbuk, jamu } \\
\text { dan lainnya. } \\
\text { d. Modal dan penjualan kunyit dapat } \\
\text { bermitra atau kerjasama dengan } \\
\text { BUMDes }\end{array}$ & $\begin{array}{l}\text { Tantangan/Hambatan (Threat/Challenges) } \\
\text { a. Petani kunyit masih menjual ke tengkulak } \\
\text { sehingga harganya rendah jika musim panen. } \\
\text { b. Belum ada pengaturan pola tanam. } \\
\text { c. Petani kunyit belum memahami cara tanam } \\
\text { yang baik dan inovatif. } \\
\text { d. Banyak warga belum tertarik untuk ikut } \\
\text { pengembangan kunyit. }\end{array}$ \\
\hline
\end{tabular}

Berdasarkan hasil wawancara dan pengamatan peneliti, maka salah satu potensi ekonomi yang memiliki peluang dan dikenal banyak oleh masyarakat Desa Pondok Meja adalah tanaman kunyit. Jika tanaman kunyit disepakati menjadi salah satu produk unggulan desa Pondok Meja, maka Tim Penyusun dapat lebih terarah dalam menggali informasi dan menyusunnya dalam sebuah matrik seperti pada tabel 4 diatas. Dengan adanya penggalian informasi seperti tabel 
diatas, maka dapat memberikan panduan untuk mencari ide-ide tentang tindakan strategis atau rencana kegiatan yang akan dilakukan secara berkesinambungan dalam mewujudkan tujuan pembangunan desa melalui melalui tahapan proses perencanaan strategis berikutnya.

\section{Mengidentifikasi isu strategis yang dihadapi organisasi.}

Tahapan kelima dari proses perencanaan strategis yaitu Identify the strategic issues facing the organization. Tahapan ini dilakukan untuk mengidentifikasi isu-isu strategis yang dihadapi oleh organisasi. Isu-isu strategis adalah pertanyaan-pertanyaan kebijakan mendasar atau tantangan-tantangan kritis yang dapat mempengaruhi mandat dan misi organisasi, produk, layanan, pembiayaan, struktur, proses dan manajemen (Bryson, 2004). Melalui identifikasi isuisu strategis juga dapat mengarahkan kepada penentuan prioritas dalam perencanaan pembangunan desa secara berkelanjutan (Alam \& Mamu, 2016). Untuk itu perlu melakukan 3 hal. Pertama, merumuskan sebuah isu sebagai pertanyaan yang dapat dilakukan oleh organisasi untuk menanggapi isu tersebut dan memiliki lebih dari satu jawaban. Kedua, membahas pertemuan atau hubungan antar tahapan (misi, mandat, dan SWOT) yang membuat isu tersebut menjadi strategis. Dan ketiga, mengartikulasikan konsekuensi dari tidak menangani isu tersebut.

Dalam proses penyusunan RPJM Desa Pondok Meja, Tim Penyusun telah berupaya mengumpulkan informasi dari masyarakat melalui musyawarah dusun. Kemudian informasi tersebut disusun dalam sebuah daftar permasalahan dan potensi untuk kemudian dilakukan pengkajian tindakan pemecahan masalah. Dalam pengkajian tersebut, dirumuskan ide-ide alternatif tentang rencana kegiatan yang dapat dilakukan untuk menyelesaikan masalah. Dari ide-ide alternatif kemudian dipilih tindakan apa yang paling layak. Tindakan yang dipilih tersebut kemudian ditetapkan sebagai rencana kegiatan dalam RPJM Desa. Akan tetapi dalam proses pengkajian tindakan pemecahan masalah tersebut, belum terlihat apa yang menjadi isu strategis. Seluruh permasalahan yang dikumpulkan, dikaji tanpa melihat hubungan dengan tahapan yang lain yaitu mandat, misi, dan SWOT. Kemudian permalasahan tersebut juga belum dinilai konsekuensinya jika terjadi kegagalan seperti adanya ancaman serius atau gagal mendapatkan keuntungan yang signifikan dari peluang yang ada. Dengan demikian belum diketahui isu apa yang sangat penting untuk ditanggapi dengan keterbatasan sumber daya atau anggaran yang dimiliki. Sehingga rencana pembangunan bisa melebar dan kurang terarah.

Tabel 5. Perumusan Isu Strategis di Desa Pondok Meja

\begin{tabular}{|c|c|c|c|}
\hline $\begin{array}{c}\text { Rumusan Isu } \\
\text { Strategis }\end{array}$ & Mandat dan Misi & Kondisi Internal & Kondisi Eksternal \\
\hline \multirow[t]{2}{*}{$\begin{array}{l}\text { Bagaimana } \\
\text { meningkatkan } \\
\text { pendapatan } \\
\text { masyarakat } \\
\text { melalui } \\
\text { pengembangan } \\
\text { kunyit sebagai } \\
\text { produk } \\
\text { unggulan desa? }\end{array}$} & $\begin{array}{l}\text { Mandat: } \\
\text { a. Bertambahnya } \\
\text { penghasilan } \\
\text { masyarakat. } \\
\text { b. Terdapatnya } \\
\text { produk unggulan } \\
\text { desa. }\end{array}$ & 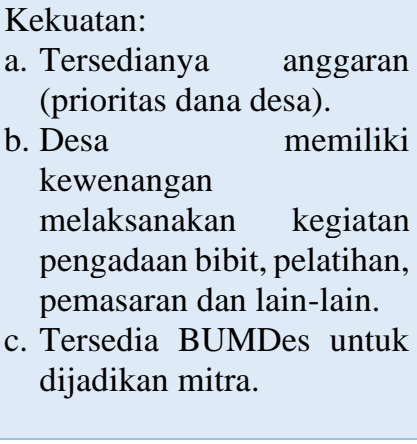 & $\begin{array}{l}\text { Peluang: } \\
\text { a. Nilai jual dan permintaan yang } \\
\text { tinggi. } \\
\text { b. Pengembangan tanaman kunyit } \\
\text { dilahan-lahan kosong atau } \\
\text { pekarangan. } \\
\text { c. Pengolahan kunyit menjadi } \\
\text { serbuk, jamu dan lainnya. } \\
\text { d. Modal dan penjualan kunyit } \\
\text { dapat bermitra atau kerjasama } \\
\text { dengan BUMDes }\end{array}$ \\
\hline & $\begin{array}{l}\text { Misi: } \\
\text { Meningkatkan } \\
\text { pendapatan } \\
\text { masyarakat dan } \\
\text { membuka lapangan } \\
\text { kerja dengan } \\
\text { mengembangkan }\end{array}$ & $\begin{array}{l}\text { Kelemahan: } \\
\text { a. Terbatasnya anggaran. } \\
\text { b. PADes masih sedikit. } \\
\text { c. Kegiatan terbatas pada } \\
\text { usulan, perlu rangkaian } \\
\text { kegiatan yang } \\
\text { komprehensif. }\end{array}$ & $\begin{array}{l}\text { Tantangan/Hambatan: } \\
\text { a. Petani kunyit masih menjual ke } \\
\text { tengkulak sehingga harganya } \\
\text { rendah jika musim panen. } \\
\text { b. Belum ada pengaturan pola } \\
\text { tanam. }\end{array}$ \\
\hline
\end{tabular}


produk unggulan desa. d. BUMDes belum ada unit usaha pertanian dan perdagangan. c. Petani kunyit belum memahami cara tanam yang baik dan inovatif.

d. Banyak warga belum tertarik untuk ikut pengembangan kunyit.

Dalam hal pengembangan potensi ekonomi lokal desa, maka berdasarkan hasil pembahasan mandat, misi, dan SWOT sebelumnya, contoh identifikasi isu strategis di Desa Pondok Meja dapat dilihat pada tabel 5 diatas. Dengan menghubungkan antara informasi-informasi tentang mandat, misi, dan SWOT, maka dapat disusun sebuah pertanyaan kebijakan mendasar yang dapat dilakukan oleh pemerintah desa. Hubungan tersebut dapat terlihat dalam memberikan jawaban terhadap pertanyaan berupa strategi potensial yang dapat dilakukan. Apabila sebuah isu belum memiliki kaitan dengan tahapan mandat, misi dan SWOT, maka isu tersebut bukanlah sebuah isu strategis atau paling penting untuk diatasi. Akhirnya rencana strategis yang disusun menjadi kurang relevan atau kurang efektif dalam mencapai tujuan yang ditetapkan.

\section{Perumusan Strategi untuk mengatasi isu strategis.}

Tahapan keenam dari proses perencanaan strategis yaitu Formulate strategies to manage the issues. Strategi dapat diartikan sebagai pola tujuan, kebijakan, program, tindakan, keputusan, dan alokasi sumber daya yang memberi gambaran apa yang dilakukannya dan mengapa melakukannya (Bryson, 2004). Tahapan ini dilakukan dalam rangka merespon atau menangani isu strategis yang telah diidentifikasi untuk digunakan dalam mencapai tujuan organisasi. Hasil dari tahapan ini adalah tersusunnya draf dari rencana strategis yang menggambarkan langkah untuk menangani isu strategis dan sekaligus mencapai tujuan organisasi. Agar strategi yang dirumuskan dapat berjelan efektif, maka stretegi tersebut harus dibangun diatas kekuatan yang ada dan mengambil keuntungan dari peluang ketika strategi itu meminimalisir atau bahkan mengatasi kelemahan dan tantangan (Bryson, 2004).

Berdasarkan pembahasan sebelumnya, bahwa Desa Pondok Meja belum mengidentifikasi apa yang menjadi isu strategis dalam penyusunan RPJM Desa khususnya terkait pengembangan potensi ekonomi lokal. Oleh karena itu, rencana kegiatan yang dirumuskan dalam RPJM Desa Pondok Meja masih bersifat rencana kegiatan mendasar dan belum memiliki arah yang diprioritaskan, sehingga rencana kegiatan pembangunan desa menjadi banyak dan beraneka ragam dari setiap potensi ekonomi yang ada. Jika diukur dengan kemampuan keuangan desa, maka tidak akan cukup untuk melaksanakan seluruh rencana kegiatan dalam RPJM Desa yang menjadi kewenangan desa. Selanjutnya dari rencana kegiatan yang ada juga belum menggambarkan strategi atau pola hubungan antar kegiatan untuk memenuhi mandat dan misi pembangunan desa. Sehingga belum terlihat pola atau hubungan dari misi pembagunan desa mana yang didukung oleh sebuah rencana pembangunan desa.

\section{Tabel 6. Perumusan Strategi di Desa Pondok Meja}

\begin{tabular}{|c|c|c|c|}
\hline Rumusan Misi & Tujuan & Isu Strategis & Strategi berdasarkan SWOT \\
\hline $\begin{array}{l}\text { Meningkatkan } \\
\text { pendapatan } \\
\text { masyarakat dan } \\
\text { membuka } \\
\text { lapangan kerja } \\
\text { dengan } \\
\text { mengembangkan } \\
\text { produk unggulan } \\
\text { desa. }\end{array}$ & $\begin{array}{l}\text { Meningkatkan } \\
\text { pendapatan } \\
\text { masyarakat dengan } \\
\text { produk unggulan } \\
\text { desa. }\end{array}$ & $\begin{array}{l}\text { Bagaimana } \\
\text { meningkatkan } \\
\text { pendapatan } \\
\text { masyarakat melalui } \\
\text { pengembangan } \\
\text { kunyit sebagai } \\
\text { produk unggulan } \\
\text { desa? }\end{array}$ & $\begin{array}{l}\text { a. Penyusunan Perdes (Prioritas } \\
\text { anggaran dan pengaturan program } \\
\text { produk unggulan desa mulai dari } \\
\text { kemitraan dan pemasaran) } \\
\text { b. Sosialisasi Budidaya Kunyit } \\
\text { c. Pembentukan Unit Usaha Pertanian } \\
\text { (BUMDes) } \\
\text { d. Peningkatan Kapasitas BUMDes } \\
\text { e. Penyertaan Modal BUMDes }\end{array}$ \\
\hline
\end{tabular}



f. Pengadaan Bibit Kunyit
g. Pelatihan Teknik Budidaya Kunyit
h. Pelatihan Teknik Panen Kunyit
i. Pelatihan Teknik Pengolahan Kunyit
j. Pembinaan usaha rumah tangga
k. Promosi produk unggulan desa
1. Monitoring

Berdasarkan rumusan misi, tujuan dan isu strategis khususnya yang bekaitan dengan pengembangan ekonomi lokal sebagaimana pembahasan sebelumnya, maka dapat dirumuskan strategi atau rencana kegiatan pembangunan desa untuk menjawab isu strategis dengan memperhatikan kondisi lingkungan, tujuan dan misi pembangunan desa sebagaimana contoh pada tabel 6 diatas. Dari setiap strategi atau rencana pembangunan pada tabel diatas juga terlihat pola hubungan dukungan untuk pencapaian tujuan dan misi. Dengan demikian rencana pembangunan desa menjadi fokus untuk mencapai tujuan dan masing-masing memiliki peran strategis dalam mendukung pencapaian tujuan tersebut.

\section{Pengulasan kembali dan pengesahan rencana strategis.}

Tahapan ketujuh proses perencanaan strategis yaitu Review and adopt the strategies or strategic plan adalah upaya untuk mendapatkan keputusan atau pengesahan secara resmi dari rencana stretagis yang telah dirumuskan, agar kemudian dapat dilanjutkan dengan tahapan pelaksanaan (Bryson, 2004). Keputusan atau pengesahan tersebut harus disetujui oleh stakeholder dan pelaksana kegiatan dengan memperhatikan pencapaian tujuan. Untuk itu stakeholder dan pelaksana kegiatan perlu diyakinkan bahwa rencana strategis yang dirumuskan adalah upaya untuk mengatasi isu strategis dan merupakan solusi yang efektif atau yang berpeluang akan berhasil. Dengan demikian, mereka dapat memberikan tanggapan dan dukungan terhadap rencana strategis tersebut.

Proses pengesahan pada penyusunan RPJM Desa Pondok Meja dilakukan pertama kali melalui musyawarah perencanaan pembangunan desa untuk membahas prioritas kegiatan dalam jangka waktu enam tahun berdasarkan hasil pengkajian tindakan pemecahan masalah dan perumusan rencana kegiatan. Kemudian hasil musyawarah tersebut dilanjutkan dengan musyawarah lanjutan untuk membahas dan menyepakati draf final RPJM Desa. Selanjutnya yang terakhir, berdasarkan hasil kesepakatan musyawarah desa, pemerintah desa menyusun rancangan peraturan desa tentang penetapan RPJM Desa. Rancangan peraturan desa tersebut dibahas dan disepakati bersama antara pemerintah desa dan BPD untuk ditetapkan sebagai peraturan desa tentang RPJM Desa.

Dalam proses pengesahan diatas Pemerintah Desa Pondok Meja telah berupaya melaksanakannya dengan baik dan sesuai peraturan. Hanya saja dalam proses pengesahan yang dilaksanakan belum terlihat pengulasan kembali yang menjelaskan dan membahas tentang strategi atau rencana kegiatan yang ada merupakan upaya untuk mengatasi isu yang paling penting yang sesuai dengan mandat atau kebutuhan dan harapan masyarakat, serta mendukung pencapaian misi pembangunan desa. Hal ini dikarenakan Tim Penyusun RPJM Desa belum mengetahui dan melaksanakan proses tahapan perencanaan strategis sebagaimana pembahasan sebelumnya. Sehingga penjelasan dalam musyawarah masih bersifat umum. Terkait pengembangan potensi ekonomi lokal secara khusus, perlu ada penjelasan secara lengkap dan terperinci karena membutuhkan pelaksanaan yang berkesinambungan. Dengan demikian masyarakat desa dapat memberikan dukungan dan komitmen tidak hanya pada saat pengesahan, namun juga pada saat pelaksanaan dan musyawarah penentuan prioritas pada tahun-tahun berikutnya. 


\section{Membangun visi organisasi yang efektif.}

Tahapan kedelapan yaitu Establish an effective organizational vision, adalah upaya untuk merumuskan atau menyusun sebuah visi organisasi yang efektif. Visi adalah gambaran atau deskripsi dari hasil yang akan terlihat atau tercapai dari keberhasilan atau kesuksesan dalam melaksanakan perencaan strategis (Bryson, 2004). Tujuannya dari visi yaitu memberikan inspirasi dan motivasi kepada anggota organisasi dan stakeholder agar memberikan dukungan dalam mencapai atau mewujudkannya. Dengan demikian, visi lebih diperlukan sebagai panduan dalam mengimplementasikan strategi daripada merumuskannya. Namun, visi juga dapat dilihat sebagai upaya untuk memandu organisasi komunitas dalam mengidentifikasi masalah dan perumusan strategi (Wheeland, 2003), sehingga perumusannya dapat dilakukan pada tahapan sebelum atau bersamaan dengan tahapan misi. Dengan demikian tahapan kedelapan ini bersifat opsional pada proses perencanaan strategis, yang mana pelaksanaan dan posisi tahapannya tergantung kepada keadaan atau kebutuhan organisasi (Bryson, 2004).

Terkait pengembangan potensi ekonomi lokal desa, khususnya dalam penelitian ini, maka agar visi dapat memberikan inspirasi dan motivasi bagi anggota organisasi dan stakeholder dalam memandu mengidentifikasi masalah dan perumusan strategi, maka pernyataan visi harus memiliki gambaran jelas tentang masa depan yang lebih baik serta didukung dengan keyakinan yang nyata (Shamir, Arthur, \& House, 1994). Maka dari itu, pernyataan visi hendaknya memiliki gambaran kesuksesan yang jelas, serta diketahui dan disepakati oleh anggota organisasi dan stakeholder.

Perumusan visi pembangunan di Desa Pondok Meja, dilakukan bersamaan dengan perumusan misi pada saat pemilihan kepala desa. Hal tersebut dilakukan sesuai dengan tuntutan peraturan dan menjadi sarana untuk menarik masyarakat untuk memilih calon kepala desa yang bersangkutan. Akan tetapi setelah kepala desa terpilih, visi tersebut tidak dibahas kembali dan disesuaikan atau disinkronisasikan dengan pokok-pokok pikiran BPD dan prakarsa unsur masyarakat pada saat proses penyusunan RPJM Desa. Sehingga visi tersebut kurang diketahui dan dipahami secara jelas oleh seluruh perangkat desa dan unsur masyarakat. Visi tersebut terkesan hanya sebagai simbol yang harus ada dalam RPJM Desa, sehingga kurang memberikan fungsi dalam proses perencanaan pembangunan desa. Agar pernyataan visi dapat memberikan pengaruh yang kuat pada keputusan dan tindakan organisasi, maka visi tersebut harus disebarluaskan dan didiskusikan, serta menjadi rujukan dalam menanggapai situasi yang dihadapi organisasi (Bryson, 2004). Terkait pengembangan potensi ekonomi lokal, hendaknya dalam rumusan visi terkandung gambaran kesuksesan dari hasil pelaksanaan rencana pengembangan produk unggulan desa. Sehingga dapat memberikan inspirasi dan motivasi dalam merumuskan dan melaksanakan rencana kegiatan pembangunan.

\section{Menyusun proses implementasi yang efektif.}

Tahapan kesembilan dari proses perencanaan strategis adalah Develop an effective implementation process. Pada tahapan ini organisasi berupaya untuk menghidupkan rencana strategis yang telah dirumuskan agar dapat dilaksanakan secara efektif dan menghasilkan nilai yang lebih nyata bagi organisasi dan stakeholdernya pada saat mandat dan misi terpenuhi atau tercapai (Bryson, 2004). Maka dari itu, sebuah organisasi tidak dapat menangani atau menyelesaikan isu-isu atau permasalahan penting dengan baik, jika rencana strategis tidak dilaksanakan dengan efektif. Untuk itu, agar dapat membangun proses implementasi yang efektif, maka diperlukan perumusan rencana aksi yang berisikan tentang bagaimana menerapkan strategi dalam jangka pendek mencakup waktu satu tahun atau kurang dari itu (Randolph \& Posner, 2002). Selain itu dalam implementasi rencana strategis juga dibutuhkan interaksi antara pelaksana dan sasaran, sehingga butuh persiapan dari berbagai aspek (Wahyudi, 2016). Untuk menyusun rencana aksi tersebut maka dari setiap strategi atau rencana kegiatan perlu digambarkan atau diuraikan beberapa komponen seperti peran dan tanggung 
jawab pelaksana, output atau keluaran yang diharapkan, langkah-langkah tindakan, tempat dan waktu pelaksanaan, sumber daya yang dibutuhkan, proses komunikasi, prosedur monitoring, dan prosedur akuntabilitas (Bryson, 2004).

Penyusunan rencana aksi di Desa Pondok Meja dilaksanakan pada saat penyusunan Rencana Kerja Pemerintah Desa (RKP Desa) yang kemudian dilanjutkan dengan penyusunan Anggaran Pendapatan dan Belanja Desa (APBDes). RKP Desa merupakan dokumen penjabaran dari RPJM Desa untuk periode satu tahun yang berisikan prioritas kegiatan yang dikerjakan pada tahun tersebut, rencana kegiatan dan rencana anggaran biaya, serta pelaksana kegiatan. Kemudian APBDes adalah rencana keuangan tahunan pemerintah desa yang disusun berdasarkan RKP Desa. Dalam dokumen RKP Desa dan APB Desa tersebut, terlihat bahwa Desa Pondok Meja telah berupaya menyusun rencana aksi setiap rencana kegiatan dengan menguraikannya dalam beberapa komponen. Hanya saja uraian tersebut masih bersifat umum dan belum terperinci dengan baik seperti luaran atau output yang bersifat umum dan sasaran kegiatan yang belum ditentukan. Dengan demikian rencana strategi yang telah disusun kemungkinan tidak dapat terlaksana dengan efektif untuk mencapai tujuan.

Terkait rencana aksi pengembangan potensi ekonomi lokal desa, maka strategi atau rencana kegiatan hendaknya diuraikan secara terperinci agar dapat terlaksana secara efektif sesuai dengan arah pembangunan untuk mencapai tujuan. Hanya saja di Desa Pondok Meja uraian dari rencana aksi masih bersifat umum dikarenakan belum menetapkan dengan jelas dari tujuan dan arah pengembangan potensi ekonomi lokal sebagaimana pembahasan sebelumnya. Sehingga rencana kegiatan pengembangan potensi ekonomi lokal menjadi kurang diprioritaskan. Padahal dalam organisasi atau komunitas, penyusunan rencana aksi tidak boleh meremehkan hal-hal yang diperlukan untuk komunikasi, pemeliharaan hubungan, dan perhatian terhadap detail operasional agar implementasi dapat berjalan sukses (Huxham, 2003).

\section{Penilaian ulang strategi dan proses perencanaan strategis.}

Tahapan yang terakhir dalam proses perencanaan strategis yaitu Reassess the strategies and the strategic planning process. Tahapan ini dilakukan setelah proses implementasi rencana strategi berjalan beberapa waktu, kemudian dinilai apakah suatu strategi tersebut harus dipertahankan, diganti dengan strategi lain, atau dihentikan dengan melihat tingkat keberhasilan strategi tersebut dalam mencapai tujuan (Bryson, 2004). Untuk itu dalam menilai strategi, program atau kegiatan, maka organisasi harus melihat indikator yang menjadi tolak ukur keberhasilan dan kegagalan dari strategi tersebut. Apabila suatu strategi belum efektif dalam mencapai target yang menjadi indikator, maka hal tersebut akan menjadi pertimbangan apakah perlu mengidentifikasi strategi, program atau kegiatan yang baru, perlu memodifikasi atau merubahnya, atau perlu menghilangkan strategi tersebut.

Di Desa Pondok Meja penilaian atau evaluasi kegiatan dilakukan pada saat penyusunan RKP Desa. Penilaian dilakukan dengan cara melihat dan memaparkan realisasi kegiatan yang dilaksanakan pada tahun sebelumnya. Terkait rencana kegiatan dalam pengembangan potensi ekonomi lokal, penilaian dipaparkan dengan mencantumkan uraian target, realisasi dan persentase ralisasi. Hanya saja target dan realisasi yang dipaparkan masih bersifat umum seperti target volume kegiatan sebanyak 1 paket dan terealisasi sebanyak 1 paket, sehingga persentase realisasi menjadi $100 \%$. Dengan demikian belum diketahui secara pasti tingkat keberhasilan dari kegiatan tersebut dalam mencapai tujuan, sebagaimana keterangan dari sekretaris desa bahwa evaluasi kegiatan baru sebatas menunjukkan kegiatan apa saja yang telah terlaksana dan belum terlaksana pada tahun anggaran tersebut.

Jika melihat tujuan pengembangan potensi ekonomi lokal desa maka, indikator penilaian dapat menggunakan ukuran seperti jumlah peningkatan pendapatan masyarakat, jumlah pengurangan pengangguran, atau jumlah pengurangan masyarakat miskin. Apabila belum memenuhi ukuran tersebut, maka dapat dibahas apa yang menjadi kekurangannya. Dengan 
demikian, melalui perbandingan antara hasil kegiatan yang dilaksanakan dengan target tersebut dapat dinilai apakah strategi atau rencana kegiatan perlu dipertahankan, diganti, atau dihentikan dalam upaya untuk mencapai tujuan pembangunan desa.

\section{KESIMPULAN}

Penelitian menunjukkan bahwa perencanaan strategis pembangunan desa dalam rangka pengembangan potensi ekonomi lokal di Desa Pondok Meja masih terdapat beberapa kekurangan. Agar perencanaan strategis pembangunan desa tersebut optimal maka dapat melakukan beberapa aspek berikut:

1. Pada saat musyawarah desa, perlu membahas dan menyepakati apa yang menjadi kebutuhan dan harapan masyarakat terkait pengembangan potensi ekonomi lokal.

2. Mengidentifikasi dan menginterpretasikan mandat formal dan informal untuk dipedomani sebagai batasan dan arah kebijakan pengembangan potensi ekonomi lokal.

3. Perumusan misi perlu memperhatikan dan menindaklanjuti kebutuhan dasar yang berasal dari interpertasi mandat pembangunan desa.

4. Menggali informasi sebanyak mungkin tentang peluang dan tantangan atau hambatan dari potensi ekonomi lokal, serta kekuatan dan kelemahan yang dimiliki oleh pemerintah desa yang dapat mendukung dan menghambat pengembangan potensi ekonomi lokal tersebut.

5. Menentukan isu strategis dalam pengembangan potensi ekonomi lokal dengan cara melihat hubungan atau pertemuan dari mandat, misi, serta informasi kekuatan, kelemahan, peluang dan tantangan atau hambatan.

6. Dalam perumusan rencana kegiatan perlu menanggapi atau menindaklanjuti isu strategis dan tujuan pengembangan potensi ekonomi lokal yang telah ditentukan sebelumnya, serta memperhatikan pola hubungan antara misi dan tujuan rencana pembangunan desa.

7. Menjelaskan hubungan rencana program dan kegiatan pengembangan potensi ekonomi lokal dengan isu strategis dan pencapaian tujuan pembangunan desa kepada unsur masyarakat dalam forum musyawarah pengesahan RPJM Desa.

8. Menjelaskan visi pembangunan desa kepada pemerintah desa dan seluruh masyarakat, serta membahasnya dalam forum musyawarah agar visi diketahui dan dipahami secara luas.

9. Merincikan uraian rencana aksi dengan detail dari setiap rencana kegiatan pengembangan potensi ekonomi lokal agar dapat diimplementasikan dengan efektif.

10. Melakukan penilaian ulang atau evaluasi terhadap rencana strategis dan proses perencanaan pembangunan desa yang telah dilakukan berdasarkan indikator keberhasilan yang terukur.

\section{Ucapan Terima Kasih}

Terima kasih kepada Pemerintah Kabupaten Muaro Jambi, Kecamatan Mestong, dan Desa Sungai Landai atas informasi dan data yang diberikan, serta terima kasih kepada Lembaga Pengelola Dana Pendidikan (LPDP) sebagai sponsor yang memberikan beasiswa sehingga penelitian ini dapat terlaksana.

\section{DAFTAR PUSTAKA}

Alam, A. S., \& Mamu, A. (2016). Isu-Isu Strategis dalam Pembangunan Desa di Kecamatan Pitumpanua Kabupaten Wajo. GOVERNMENT: Jurnal Ilmu Pemerintahan, 95-102.

Bryant, J. (2002). The six dilemmas of collaboration: Inter-organisational relationships as drama. Wiley. 
Bryson, J. M. (2004). Strategic Planning For Public and Nonprofit Organizations : a Guide to Strengthening and Sustaining Organizational Achievement (3rd ed). San Franscisco: Jossey-Bass.

Bryson, J. M. (2018). Strategic planning for public and nonprofit organizations: A guide to strengthening and sustaining organizational achievement. John Wiley \& Sons.

Bryson, J. M., \& Alston, F. K. (2010). Creating and implementing your strategic plan: A workbook for public and nonprofit organizations (Vol. 1). John Wiley \& Sons.

Bryson, J. M., Crosby, B. C., \& Bryson, J. K. (2009). Understanding strategic planning and the formulation and implementation of strategic plans as a way of knowing: The contributions of actor-network theory. International Public Management Journal, 12(2), 172-207.

Creswell, J. W. (2016). Research design: pendekatan metode kualitatif, kuantitatif, dan campuran. Terjemahan Achmad Fawaid dan Rianayati Kusmini Pancasari. Yogyakarta: Pustaka Pelajar.

Dandekar, H. C. (2015). Rural Planning: General (J. D. B. T.-I. E. of the S. \& B. S. (Second E. Wright, ed.). https://doi.org/https://doi.org/10.1016/B978-0-08-097086-8.74039-6

Dinas Pemberdayaan Masyarakat dan Desa. (2020). Sistem Keuangan Desa. Muaro Jambi: Badan Pemeriksa Keuangan dan Pembangunan (BPKP).

Eko, S. (2014). Buku "Desa Membangun Indonesia." Sleman, Yogyakarta: Forum Pengembangan Pembaharuan Desa (FPPD).

Huxham, C. (2003). Theorizing collaboration practice. Public Management Review, 5(3), 401423.

Light, P. C. (1998). Sustaining innovation: Creating nonprofit and government organizations that innovate naturally. Jossey-Bass.

Martati, I., \& Syarifuddin, A. (2013). Model Penciptaan Lapangan Kerja Melalui Pengembangan Ekonomi Lokal Pada Kecamatan Samarinda Ilir. Jurnal Manajemen Dan Kewirausahaan, 15(2), 123-130.

Miles, M. B., \& Huberman, A. M. (1994). Qualitative data analysis: An expanded sourcebook. Thousand Oaks, California: Sage.

Muhammad, M. (2017). Perencanaan Pembangunan. In Sekolah Tinggi Ilmu Administrasi AlGazali Barru. Sekolah Tinggi Ilmu Administrasi Al-Gazali Barru.

Nugroho, I., \& Dahuri, R. (2016). Pembangunan Wilayah: Perspektif ekonomi, sosial dan lingkungan. LP3ES.

Nutt, P. C. (2002). Why decisions fail: Lessons about what works, what doesn't and why from a 20-year study of 400 decisions. San Francisco, CA.: Berrett-Koehler. Additional Information from Ohio State University. Retrieved June, 24, 2002.

Rainey, H. G. (2009). Understanding and managing public organizations. John Wiley \& Sons.

Randolph, W. A., \& Posner, B. Z. (2002). Checkered flag projects: 10 rules for creating and managing projects that win! FT Press.

Saragih, J. R. (2015). Perencanaan wilayah dan pengembangan ekonomi lokal berbasis pertanian: teori dan aplikasi. Pustaka Pelajar.

Sawhill, J. C., \& Williamson, D. (2001). Mission impossible?: Measuring success in nonprofit organizations. Nonprofit Management and Leadership, 11(3), 371-386.

Sayuti, H. M. (2011). Pelembagaan Badan Usaha Milik Desa (BUMDes) sebagai penggerak potensi ekonomi desa dalam upaya pengentasan kemiskinan di Kabupaten Donggala. Jurnal ACADEMICA Fisip Untad, 3(02), 717-728.

Shamir, B., Arthur, M. B., \& House, R. J. (1994). The rhetoric of charismatic leadership: A theoretical extension, a case study, and implications for research. The Leadership Quarterly, 5(1), 25-42.

Sidik, F. (2015). Menggali potensi lokal mewujudkan kemandirian desa. JKAP (Jurnal 
Kebijakan Dan Administrasi Publik), 19(2), 115-131.

Sofianto, A. (2017). Kontribusi Dana Desa terhadap Pembangunan dan Pemberdayaan Masyarakat di Kebumen dan Pekalongan. Matra Pembaruan: Jurnal Inovasi Kebijakan, $1(1), 23-32$.

Susanti, E. A. (2013). Pengembangan ekonomi lokal dalam sektor pertanian (studi pada Kecamatan Pagelaran Kabupaten Malang). Jurnal Administrasi Publik, 1(4), 31-40.

Thomas, J. C., \& Thomas, F. D. R. (1995). Public participation in public decisions: New skills and strategies for public managers. Jossey-Bass.

Wahyudi, A. (2016). Implementasi rencana strategis badan pemberdayaan masyarakat dan desa dalam upaya pengembangan Badan Usaha Milik Desa di Kabupaten Kotawaringin Barat. Jurnal Ilmiah Administrasi Publik, 2(2), 99-103.

Wheeland, C. M. (2003). Implementing a community-wide strategic plan: Rock Hill's Empowering the Vision 10 years later. The American Review of Public Administration, 33(1), 46-69.

Zuhaidha, S. A., Santoso, S., \& Maesaroh, M. (2014). Perencanaan strategi pengembangan ruang terbuka hijau Kota Semarang (studi kasus: Hutan Wisata Tinjomoyo). Journal of Public Policy and Management Review, 3(2), 390-399.

Zulkarnaen, R. M. (2016). Pengembangan potensi ekonomi desa melalui badan usaha milik desa (Bumdes) Pondok Salam Kabupaten Purwakarta. Dharmakarya, 5(1). 